\title{
Tértermelés a budapesti várostérség peremén - amit a gazdaság morfológiája elárul
}

\section{The metropolitan periphery around Budapest: an economic morphology}

\author{
SZABÓ TÜNDE
}

SZABó Tünde: doktorjelölt, Szegedi Tudományegyetem, Földtudományi Doktori Iskola; szabo.tunde.sm@gmail.com

KULCSSZAVAK: nagyvárosi periféria, tértermelés, gazdasági fejlődés, politikai gazdaságtan

ABSZTRAKT: A városok politikai gazdaságtani szempontú elemzésére egyre több magyar példa áll rendelkezésre a szakirodalomban. Ezek túlnyomó része azonban ritkán lép ki a központi város teréből és szolgál magyarázattal a szuburbán vagy az urbanizálódó rurális térségek átalakulásáról. Tanulmányom a nagyvárosi perem gazdasági térszerkezetének vizsgálatára vállalkozik, értelmezi a periferikus tér urbanizációs folyamatait és következtetéseket von le a tértermelés peremvidéki jellegzetességeiről. Az urbanizációs folyamatok kapcsán vizsgálom azt, hogy a városi perem gazdaságszerkezete visszatükrözi-e az érett kapitalista várostérségekben jellemző specializálódást, illetve a gazdasági tevékenységek övezetes elrendeződését. Ehhez statisztikai adatokat, valamint egy geokódolt cégadatbázist használok, amely a várostérség 56 települését és 1312 cégét fogja át. Eredményeim szerint sem az ágazati, sem a funkcionális specializáció jeleit nem figyelhetjük meg a periférián. Ezek alapján a budapesti metropolisztér a globális értéktermelés és -elosztás köreibe kevéssé integrált városi gazdaságnak tűnik, amely kevés speciális szolgáltatást és terméket képes nyújtani a külpiacok számára. A cégadatok térképi megjelenítése a cégek eltérő koncentrációját mutatja a településszerkezeten belül: egyes települések képesek vállalkozói zónákba tömöríteni a periférián megtelepedő cégeket, míg mások nem képesek szabályozni a spontán telephelyválasztást. Az egyes helyek eltérő módon kezelik a neoliberalizációs folyamat rájuk nehezedő nyomását, más és más módon sajátítják el a neoliberális átalakulást. Ebből arra következtethetünk, hogy - a társadalom helyi viszonyain túl - az állam és a tőke viszonyában helyi eltérések lehetnek. Feltételezésem szerint a vállalkozások koncentrált vagy széttagolt letelepülése a helyi állam és a befektetői tőke településenként eltérő kapcsolataira utal, ami a tér alakításának mechanizmusait is módosítja. Ezek feltárásához interjúkat készítettem a periféria egy településcsoportjában. A beszélgetések segítettek feltárni azokat az ellenőrzési mechanizmusokat, amelyeket az állam a tér termelése felett gyakorol.

Tünde SZABÓ: PhD candidate, Doctoral School for Earth Sciences, University of Szeged; szabo.tunde.sm@gmail.com

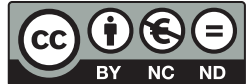


KEYWORDS: metropolitan periphery, production of space, economic development, political economy

ABSTRACT: There is a growing number of urban researches applying analytical tools of political economy available in Hungarian literature. However, the analyses refer almost entirely to the metropolitan core (in most cases, to Budapest), and rarely provide explanations of the mechanism producing suburban, or even increasingly urbanising rural spaces at the very periphery of a metropolis. This study aims to investigate the spatial structure of economic activity along the metropolitan edge around Budapest. Based on the spatial structure of entrepreneurial activity in the periphery, my goal is to interpret the urbanisation process and some particular findings on the political economy of the metropolitan periphery. I address the question of whether spatial morphology of joint corporations at the Budapest metropolitan periphery reflects typical spatial patterns of mature capitalist cities, i.e. specialisation and zonal settling of economic activity in the metropolitan region.

Methodologically speaking, I use statistical data as well as a self-collected database of joint corporations, encompassing the whole metropolitan area of 56 settlements and 1312 companies. The data were geocoded and plotted. Based on the research findings I argue that there is neither sectoral, nor functional specialisation of joint corporations to be observed at the metropolitan periphery. This implies that urbanisation forms of mature capitalist city regions cannot be clearly identified around Budapest. The spatial economy of the Budapest metropolitan area seems rather to be boosted by the scale and size of the metropolitan market itself, than by global market integration. Based on the data analysis of joint corporations, the Budapest metropolitan area can provide just a few specialised services and products for the global market, and is able to an only limited degree to be integrated into the global commodity chains and production networks.

Plotting corporations' locations on the map shows a distribution of enterprises different in one settlement to that of another. Some local governments are able to concentrate economic activity to a few business parks within their administrative boundaries, but others seem to lose control over settling economic activities systematically. Some places seem to successfully internalise the pressure of neoliberal transformation, while others prove to be unresponsive to them. I argue that these differences are being produced by dissimilar relations between state and capital when comparing one settlement to another. I assume that the locally determined relations of state and capital lead to some variations in producing local economic spaces. To test that assumption I delimited a case-study area of three settlements (all of them showing dissimilar distribution pattern of entrepreneurial activities), where I made interviews with local decision makers, professionals and an investor. Discussing the interrelations between capital, state and place contributed to reveal state control and its mechanisms over producing places of economic activity. My interviewees pointed out the market-influencing practice and techniques of the local state, which reflects the neoliberal transformation of the capital-state interrelation.

\section{Bevezetés}

A budapesti nagyvárosi térség perifériája a földrajzi vonatkozású társadalomkutatás számára kevéssé ismert terület. Keveset tudunk a periféria társadalmáról, és a kutatások itt is főleg a társadalmi elitre vonatkoznak (Csanádi, Csizmady 2002; Szirmai 2011; Szirmai et al. 2011). Ennél is kevésbé világos, hogyan működik a periféria gazdasága. Empirikusan nem vagy nem megfelelően bizonyított feltételezéseket fogadunk el tényként, amikor például a gazdasági szuburbanizációról, a periférián virágzó termelésről, a periferikus cégek transznacionális hálózatokba ágyazottságról vagy éppen a globális töltetű met- 
ropolizációról beszélünk. Szintén csupán feltételezéseink vannak a periféria formálódásának (termelésének) mechanizmusairól. Nem ismerjük annak az összjátéknak a módját, ahogy a tér alakítását ellenőrző szereplők egyéni cselekvésein, intézményi gyakorlatain, hálózati kapcsolatain keresztül újjáalakul a periféria területhasználata, tájképe. A magyar vonatkozású városi kormányzás irodalma fontos jelenségekre hívja fel a figyelmet, amikor a városi rezsimek vagy vállalati kapcsolatok helyett létező informális viszonyokról beszél a hely termelése, a helyi gazdaságfejlesztés kapcsán (Pálné Kovács 2009, 2010). Tanulmányom célja a budapesti nagyvárosi periféria gazdaságának vizsgálata, annak térbeli szerveződésének megértése. Nagyvárosi peremként vagy perifériaként hivatkozom a nagyvárosi térség központi városon kívül eső vidékeire, a közel sem periferikus, „érett” szuburbán településekkel együtt. A vizsgált terület Budapest szükebb és tágabb vonzáskörzetében 56 településre terjed ki. ${ }^{1}$

Vajon a globálissá váló termelés Budapest környékén is átszervezi a gazdaság tereit, hogy a világszinten szerveződő termelési hálózatok és értéktermelési láncok helyi tevékenységeinek helyet adjon? Mi jellemzi a periféria gazdaságának térbeli szerkezetét? A neoliberális átalakulás vajon hasonló urbanizációs folyamatokat hoz létre Budapest környékén, mint az érett kapitalizmus városainak peremén? Milyen mechanizmusok termelik újjá a nagyvárosi periféria tereit? A tanulmányban a nagyvárosi periférián jelen lévő cégek profilját és az általuk meghatározott morfológiát vizsgálom. Ehhez online cégadatbázisok felhasználásával összeállítottam az 56 településen jelen lévő, 500 millió forintot meghaladó éves árbevételü cégek adatbázisát, majd postacím alapján térképeztem azok telephelyeit. A nagyvárosi perem gazdasági morfológiáját létrehozó mechanizmusok megértéséhez interjúkat készítettem az esettanulmányként választott településeken, így kerülve közelebb a periféria politikai gazdaságtanának megértéséhez.

\section{A periféria átalakulása a szakirodalomban: városföldrajzi, városkutatási és politikai gazdaságtani értelmezések}

Azóta, hogy a társadalomtudományokat nem köti gúzsba a pozitivista tudományfelfogás, számtalan filozófiai irányzat és felfogás igyekezett újraértelmezni a földrajz tradicionális kutatási témáit, fogalmait. A posztstrukturalizmus, a dekonstrukció, a pszichoanalízis vagy éppen a neomarxizmus újabbnál újabb értelmezéseket kínáltak, ezzel megkérdőjelezve az analitikus földrajzi kutatás kizárólagosságát, a kutatási témákat, az alkalmazott módszereket és a kutatás morális felfogását (Kiss 2014; Peet, Hartwick 2009). Ezek a posztpozitivista társadalomelméleti iskolák elutasítják a kizárólagos és mindent átfogó magyarázatokat a társadalmi változásokról. Ebben a diszciplináris gazdagságban a városföldrajz értelmezési keretei már nem elegendőek a társadalmi változások föld- 
rajzi összefüggéseinek keresésére. Jóval nagyobb rálátást biztosít kutatásom tárgyára - a később részletezett nagyvárosi perifériára - a városkutatás, ám ennek fókuszából eltűnik a tér. Ez a hiátus arra utal, hogy a földrajz hagyományos kutatási tárgyai elégtelenül fordíthatók le a posztpozitivista tudományosság nyelvére. A városi tér klasszikus fogalmai - mint például a centrum-periféria viszonyok, az urbanizációs ciklusok - nem operacionalizálhatók egyformán mindkét megközelítésben. Elismerve korlátaikat - például a klasszikus gazdaságelméletek politikai vakságát és hatalommal szembeni elfogultságát vagy a kritikai elméletek túlzott strukturalizmusát - mindegyik látásmódot hasznosnak tartom a megismerés szempontjából.

A várossal, különösen annak perifériájával foglalkozó pozitivista társadalomelméleteket a neoklasszikus térgazdaság eszmerendszere köti össze. Eszerint az értéktermelés térbeli igényei alakítják a nagyvárosi térségek szerkezetét. A globális értéktermelési láncokba szerveződő cégek szolgáltatásokra épülő, méretgazdaságos városi gazdaságokat keresnek telephelyeik számára. Ez a világgazdasági nyomás a városok fokozott alkalmazkodását követeli. Ebben a gondolatrendben az „új gazdaságföldrajz” nagy befolyásra tett szert: a regionális méretűvé terjesztett városban továbbra is a távolság gazdaságszervező, de legalábbis gazdaságot befolyásoló működésének matematizált leírása áll a középpontban (Davoudi 2003; Fujita 2002; Krugman 2000; Venables 2008). A nagyvárosok belső szerkezetének átrendeződése a posztfordi termelésimód-váltás eredménye. Mind a társadalom térbeli rendje, mind annak mechanizmusai egyenes következményei a gazdaság strukturális és szervezeti átalakulásának (Gentile, Tammaru, van Kempen 2012). A teret középpontba helyező vizsgálatok gyakran kutatott témája az egyenlőtlenségek alakulása, a társadalmi mozgások vagy éppen az ezek következtében átalakuló térhasználat. Központi fogalom a városi térség morfológiai átalakulása és azok modellbe foglalása (Champion 2001; Maier, Tödtling 2001; Mainz 2005; van den Berg 1982). Jellegzetesen illik e narratívába a posztszuburbanizációs folyamatok elemzésének szemlélete (Bontje, Burdack 2011; Brake 2001; Phelps, Wu 2011; Sieverts 1999), nem kevésbé a közép- és kelet-európai városok átmeneti gazdaság- és társadalomszerkezetét önálló modellként elemző posztszocialista urbanizáció értelmezése (Burdack, Herfert, Rudolph 2005; Kovács 2010; Sýkora, Bouzarovski 2012). A neoklasszikus térgazdaság narratíváját - a városok globális integrációjának történeti fonalára felfüzve - széles körüen alkalmazzák a fóáramú városkutatásban (többek között Hall 2009; Malmberg 2009; Sassen 2001; Scott, Agnew, Soja, Storper 2001).

Bár a földrajzi környezetet figyelembe vevő posztpozitivista társadalomelméletek közé sorolható elméletek köre ennél jóval szélesebb (többek között az itt nem tárgyalt posztmodern város vagy éppen a „sokszínű gazdaság” által alakított városi tér), a következőkben a strukturalista-kritikai tértermelés „kerettörténetébe" illesztve utalok a városi periféria szempontjából érdemi elméletekre. Ezek a tér felfogásában térnek el az előbbiektől. Elvetik az észleléstől független tér képzetét és érvelnek a tér folyamatos „termelése” mellett: a térbeli folya- 
matokat a cselekvők az adott társadalmi rendszer intézményi, politikai és hatalmi berendezkedésének szabályait követve folyamatosan alakítják (Kitchin 2009; Lefebvre 1991). A strukturalizmus és marxizmus eszmei keretein belül jöttek létre a klasszikus politikai gazdaságtan elméleti alapjai, amelyek szerint a politika és a gazdaság jelenségei kizárólag együtt tanulmányozhatók. Többek között David Harvey hozzájárulása volt jelentős a marxista politikai gazdaságtan „városiasításában”, azaz a kapitalizmus térszervezési mechanizmusainak feltárásában. Neomarxista értelmezésben a város fizikai megjelenése a tőke felhalmozásának szabályait tükrözi (Harvey 1978, 1990; Peet, Hartwick 2009). A töke újratermelését (a befektetések jövedelmezőségének megőrzését) a város időről időre történő újraalkotásával lehetséges elérni. Az urbanizáció frontálzónájának kiterjedése a korábbi peremre - azaz a területhasználat változása, az ingatlanpiac, a befektetések és a tőkekivonás alakulása - a térben egyenlőtlen tőkehozamokat tükrözi. A neomarxista politikai gazdaságtan számára a város a társadalmi egyenlőtlenségeknek, a hatalom dominanciájának és a kapitalista termelési rendnek a térbeli kifejeződése, amely olyan feszültségekben mutatkozik meg, mint a tömeges szuburbanizáció, a szegregáció, a belső városnegyedek leromlása és a gettósodás (Kaminer, Robles-Durán, Sohn 2011; Smith 1982; Timár 1999; Timár, Váradi 2001). Az egyenlőtlen hatalmi viszonyok és azok következményeinek elemzése így értelmezési keretet ad ugyanazon folyamatok számára, amelyet a klasszikus társadalomtudományok nem voltak képesek megfelelően leírni. A mainstream társadalomelméletek posztfordi átmenete a neomarxista politikai gazdaságtan felől nézve túlfelhalmozási válság, amely részben magyarázható az egyenlőtlen fejlődést kihasználó folyamatok összeomlásával (Harvey 1978; Smith 1982). A neoliberalizáció fokozódó városiasodása a hely és annak termelése felett rendelkező szereplők intézményesült összjátékát takarja (Boros 2010; Brenner, Theodore 2002; Golubchikov, Phelps 2011). A városi tér mint erőforrás a tőke újratermelésének (körforgásának) kitüntetett eszköze: a városi és városperemi tér a neoliberális gazdaságpolitika intézményi laboratóriuma, ahol a tőkehozamokat meghatározza az elhelyezkedés. A városi tér elemzésének politikai gazdaságtani megközelítése különösen célszerűnek tűnik a neoliberális termelés- és államszervezés korában: a tőke újratermelésének neoliberális rendszere ugyanis minden korábbinál (a keynesi és az irányított kapitalizmusnál) tisztábban mutatja a kapitalista rendszer működésének mechanizmusait (Bodnár 2000).

\section{Lényegi eltérés a neoklasszikus és neomarxista érvelésben: az állam szerepe}

Az előzőekben két gondolati keretet - a neoklasszikust és a strukturalista-kritikait - igyekeztem bemutatni, amelyeken keresztül értelmezhető a városok, ezen belül is a nagyvárosi peremtérségek átalakulása. Mindkét gondolati keretben értelmezhető a város változásának minden folyamata, feltárhatók annak 
oksági viszonyai, állitások fogalmazhatók meg működési mechanizmusairól. Érdemi különbség mégis van közöttük: míg a konzervatívabb tudományfelfogás egyes struktúrák, folyamatok, viszonyok kimerítő elemzését teszi lehetővé, addig a tértermelés gondolati keretében a hangsúly a tőke és az állam közötti összjátékon van. Lényeges, hogy az eltérő gondolati keretek alkalmazása egymással ellentétes megállapításokhoz vezethet, és kölcsönös kételyeket ébreszt azok hiteléről. Az állam szerepének megítélése a nagyvárosi periféria termelésében egy az ellentmondásos témák közül (Hirt 2013). A neoklasszikus társadalomelméleten nyugvó társadalom-földrajzi értelmezések az állam újraelosztó és szabályozó szerepének gyengülését jelzik a neoliberális átalakulás folyamán. A volt szocialista blokk városkutatással foglalkozó irodalma például gyakran hivatkozik a piacgazdasági átmenet időszakára mint tranzíciós, köztes periódusra, amelyben a politikai és intézményi berendezkedés, a kulturális és kognitív viszonyok, valamint a területhasználati és városképi körülmények igazodnak az új termelési rendhez (Axenov, Brade, Bondarchuk 2006; Stanilov 2007; Sýkora, Bouzarovski 2012). A neoklasszikus társadalomelméleten nyugvó társadalomföldrajzi elemzés a posztszocialista állam szerepének egyediségét elfogadva, azt meg nem kérdőjelezve tulajdonképpen a befejezetlen neoklasszikus állam ideáját ápolja, amikor a várostérségek posztszocialista térszerkezet-átalakulásáról ír (Bodnár 2000). A posztszocialista átalakulás azonban a globális szerkezetátalakulás háttere előtt zajlik, így nehezen megfogható, hogy a globális és helyi kényszerítő körülmények pontosan milyen hatást gyakorolnak a nagyvárosi térségek átalakulására (Berki 2014; Enyedi 2011; Kovács 2005a, 2005b). A társadalomföldrajz ismét a neoklasszikus érvelést veszi át: az állam kizárólag a privatizáció és dereguláció által megszabott pályán haladhat, utat nyitva a piac és a tőke rendszerszabályozó mechanizmusai számára (Borén, Gentile 2007). Szerepe a piaci folyamatok háborítatlanságának biztosításán felül a fejlődés, fejlesztés irányítására szorítkozhat (Golubchikov, Phelps 2011).

Ezzel szemben a városrégiók belső szerkezetének - ezáltal azok perifériájának - formálásában a strukturalista-kritikai kerettörténet szerint lényegi szerepet játszik az állam (Brenner, Theodore 2002) azzal, hogy a magántőke legfőbb partnerévé válik (Timár 2010). A posztszocialista városok neoliberális átalakulásában éppen az állam mint az erőforrások újraelosztását irányító nagy hatalmú szereplő hat legnagyobb mértékben a nagyvárosi periféria tértermelésére. Golubchikov és Phelps (2011) kiemeli, hogy a posztszovjet viszonyok között az elővárosi tér termelésének folyamata elsősorban politikailag (és nem üzleti vállalkozások vagy városfejlesztési stratégiák által) meghatározott, ahol a „politika" a hatóságok közötti patrónuskapcsolatok bürokratizált rendszerét jelenti (Golubchikov, Phelps 2011, 438.). Magyar példákra hivatkozva Kulcsár és Domokos (2005) szintén a politikai szereplők kulcshelyzetét hangsúlyozzák. A magyar önkormányzatoknak érdemi szerepük van a helyi növekedési koalíciók, „rezsimek" összeállításában és fenntartásában, ezért a gazdasági elitnek sincs kizárólagos ellenőrző szerepe a helyi politika fölött (a fordított jellegü kapcsolat inkább 
jellemző). Az állami újraelosztást felpörgető, nagy tömegű fejlesztési források pedig nemcsak a helyi, de az állami szintet is újra megerősítették: az állami forrásokért történő versengés, illetve fordítva, az önkormányzatok „kézből etetése” szintén az állam saját intézményrendszerén keresztül gyakorolt hatalmának konszolidációját eredményezi (Kulcsár, Domokos 2005). Az állam tehát az uralkodó narratíva által sugalltnál mindig is nagyobb mértékben nyúlt bele a szavak szintjén egyre szabadabbá váló piaci folyamatokba, legfeljebb az erre szolgáló eszközei változtak.

\section{A periferikus gazdaság morfológiája: méretgazdaságosság és specializáció}

Korábbi kutatások már foglalkoztak a budapesti nagyvárosi tér belső kapcsolatainak átalakulásával, a budapesti városrégióban zajló posztszuburbán folyamatokkal (Keserű 2013). Néhány empirikus elemzés a foglalkoztatottak ingázását vizsgálva megállapította a központi város foglalkoztatási központjellegének oldódását, és főként az elővárosi térben, kisebb mértékben a nagyvárosi periférián elhelyezkedő városok foglalkoztatottakat vonzó képességének erősödését (Kovács, Szabó 2013; Szabó, Szabó, Kovács 2014). Mindez utal a gazdasági szervezetek városi térben történő szétszóródására, ami a nyugat-európai városok urbanizációs trendjeibe illő folyamat. Mindez vajon azt jelenti, hogy a budapesti várostérségen belül is megjelennek a globális termelésnek és elosztásnak azon körei, amelyek az európai városi perifériákat formálják?

A posztszuburbanizációs folyamatok új központokat hoznak létre a városrégió terében, amelyek versenyeznek a várostérségi központtal a beruházásokért. Az átalakuló központrendszer oldja a várostérség koncentráltságát. A posztszuburbán periféria egyenlőtlenül sűrűsödik és ritkul, a fejlődő központok környezetében urbanizáltabb, azoktól távolabb vidékiesebb jellegzetességeket mutatva. A várostudományi irodalom szerint az új térszerkezeten belül nem lehet egyértelműen központot és környéket lehatárolni, sokkal inkább klaszterek, magok, csomópontok halmazáról beszélhetünk (Danielzyk 2012). Az újraközpontosodás legfóbb (a neomarxista értelmezés szerint egyik) hajtóereje a várostérség gazdaságának igazodása a globális termelés és fogyasztás igényeihez. A várostérségi gazdaság morfológiájára jellemző, hogy a magas hozzáadott értékű üzleti szolgáltatások a legszélesebb körű nemzetközi kapcsolatrendszert nyújtó központokat választják, míg a személyi és az elosztó üzletágakat kiszolgáló szolgáltatások szétszóródnak a szuburbán térben, vagy a közepes méretű városokban találják meg a helyüket (Bose 2001; Brake 2001). Azaz a nagyvárosi perem átalakulásában elsősorban a termeléshez és elosztáshoz köthető szolgáltatások játszanak érdemi szerepet. Ez azokra a cégekre jellemző, amelyek áruikkal, szolgáltatásaikkal várostérségen túli területeket is ellátnak (Daniezyk 2012). 
Az üzleti szolgáltatások bizonyos formáit a várostérségben megtelepedő tematikus parkok vonzzák magukhoz (Brake, Einacker, Mäding 2005). A várostérségi övezet új központjainak erősödése a policentrikus nagyvárosi térszerkezet felé tolja el a városi struktúrát (Hall, Pain 2006). Az új központokban megtelepedett cégek között sajátos kapcsolat alakulhat ki. Ez a kapcsolat munkamegosztáson alapul: egyes központok a nagyvárosi gazdaság méreteit kihasználva specializálódnak bizonyos termelési vagy üzleti tevékenységekre, városi funkciókra. A szakosodás egyben a várostérség globális termelési integrációjának a fokmérője (Burger, Meijers 2012; De Goei, Burger, van Oort, Kitson 2010; Meijers 2005). Empirikus kutatások azonban mindeddig azt mutatták, hogy míg a nagyvárosi térségeken belül a városok közötti ágazati specializáció csökken (azaz minden város a gazdasági tevékenységek minél szélesebb tárházát igyekszik magához vonzani), a várostérséget alkotó központok egyre inkább funkciók (termelés, cégirányítás, ügyfélkapcsolat stb.) alapján szakosodnak.

Az előzőek alapján azt várnánk, hogy a nyugat-európai mintákhoz hasonlóan a globális értéktermelési láncok helyi tevékenységeinek megjelenésével megindult a fővárosi székhelyű cégek városhatáron kívülre települése, illetve új vállalkozások megtelepedése a nagyvárosi peremen. A központi város és a nagyvárosi perem gazdaságszerkezete között idővel arányeltolódás következik be a termeléshez, elosztáshoz köthető szolgáltatások és általában a kevésbé összetett szolgáltatások javára a peremen. A budapesti várostérség elmúlt bő tíz évét vizsgálva (1. táblázat) ezzel szemben a nagyvárosi peremtérségek gazdaságának általános diverzifikációját figyelhetjük meg. ${ }^{2}$ Növekszik a kereskedelem, valamint az elosztás ágazatainak aránya, míg ugyanezek a központi városban veszítenek jelentőségükből. Ugyanakkor a gazdasági szolgáltatások-

1. táblázat: A működő társas vállalkozások számának változása, 2001, 2008, 2012 Number of operating companies by group of sectors, 2001, 2008, 2012

\begin{tabular}{lrrrrrr}
\hline \multicolumn{1}{c}{ Ágazatcsoportok } & \multicolumn{3}{c}{ Budapest } & \multicolumn{3}{c}{ Pest megye } \\
\cline { 2 - 7 } & 2001 & 2008 & 2012 & 2001 & 2008 & 2012 \\
\hline Feldolgozóipar & 14641 & 11012 & 8848 & 5598 & 5570 & 5312 \\
Kereskedelem és javítás & 37123 & 29094 & 29681 & 10375 & 11743 & 12856 \\
Szállítás, raktározás, távközlés & 4339 & 3997 & $3161^{*}$ & 1774 & 2402 & $2345^{*}$ \\
Gazdasági szolgáltatások** & 63046 & 62406 & 73008 & 11057 & 18251 & 22471 \\
Személyi és közösségi szolgáltatások*** & 13814 & 15759 & 14942 & 3423 & 5303 & 5724 \\
\hline
\end{tabular}

* Távközlés nélkül.

**TEÁOR '03: Pénzügyi, biztosítási tevékenységek; Ingatlanügyletek, gazdasági szolgáltatások; TEÁOR '08: Információ, kommunikáció; Pénzügyi, biztosítási tevékenységek; Ingatlanügyletek; Szakmai, tudományos, müszaki tevékenységek; Adminisztrativ és szolgáltatást támogató tevékenységek.

***TEÁOR '03: Oktatás; Egészségügy, szociális ellátás; Egyéb közösségi személyi szolgáltatások; Egyéb tevékenységek; TEÁOR '08: Közigazgatás, védelem; Oktatás; Humán-egészségügyi, szociális ellátás; Művészet, szórakoztatás, szabadidő; Egyéb szolgáltatások.

Forrás: KSH. 
ban tevékenykedő cégek számának növekedése a peremen inkább a térségi gazdaság sokszínűbbé válását tükrözi, mintsem a központ és a periféria viszonylatában várt specializációt. Úgy tünik, hogy bár a kereskedelem és elosztás ágazatai egyre inkább előnyben részesítik a központi városon kívüli telephelyeket (ezzel egyfajta ágazati specializáció irányába tolva a centrum-periféria különbségeket), mindezzel egy időben jóval kiegyensúlyozottabbá is válik a központi város és térségének gazdaságszerkezete. A statisztikai adatok tehát egyszerre jeleznek specializációt a peremen és a központi város gazdaságszerkezetéhez történő igazodást.

Sajnos a nagyvárosi periférián jelen lévő cégekről elvétve készült átfogó elemzés (Kukely 2006; Sági 2000). A statisztikai cégadatok kutatási célú alkalmazása ezen a területi léptéken nehézkes, az adatok gyakran megbízhatatlanok. Az adatgyűjtés során ezért saját adatbázist állítottam össze, amelyhez több cégadattár felületét használtam (Opten, HVG Céginfótár, CompLex Céginfo). A három adatbázis adatait összevetettem, hogy az inaktív cégeket kiszűrjem, illetve a legfrissebb megadott árbevételadattal dolgozzak. Az így előállt adatbázis tartalmazza a vizsgált terület 56 településének cégeit, postacímmel, a fö tevékenység megnevezésével és az elérhető legfrissebb (2012, 2013) árbevételadattal (1. ábra). Az adatbázis a legalább 500 millió Ft árbevétellel rendelkező cégeket tartalmazza, összesen 1312 céget. A cégek telephelyeinek geokódolása a Google Fusion és Google Earth szolgáltatásokkal történt,

1. ábra: A cégek éves árbevétele a nagyvárosi periférián, 2012/2013 Annual revenues of joint corporations on the metropolitan periphery, 2012/2013

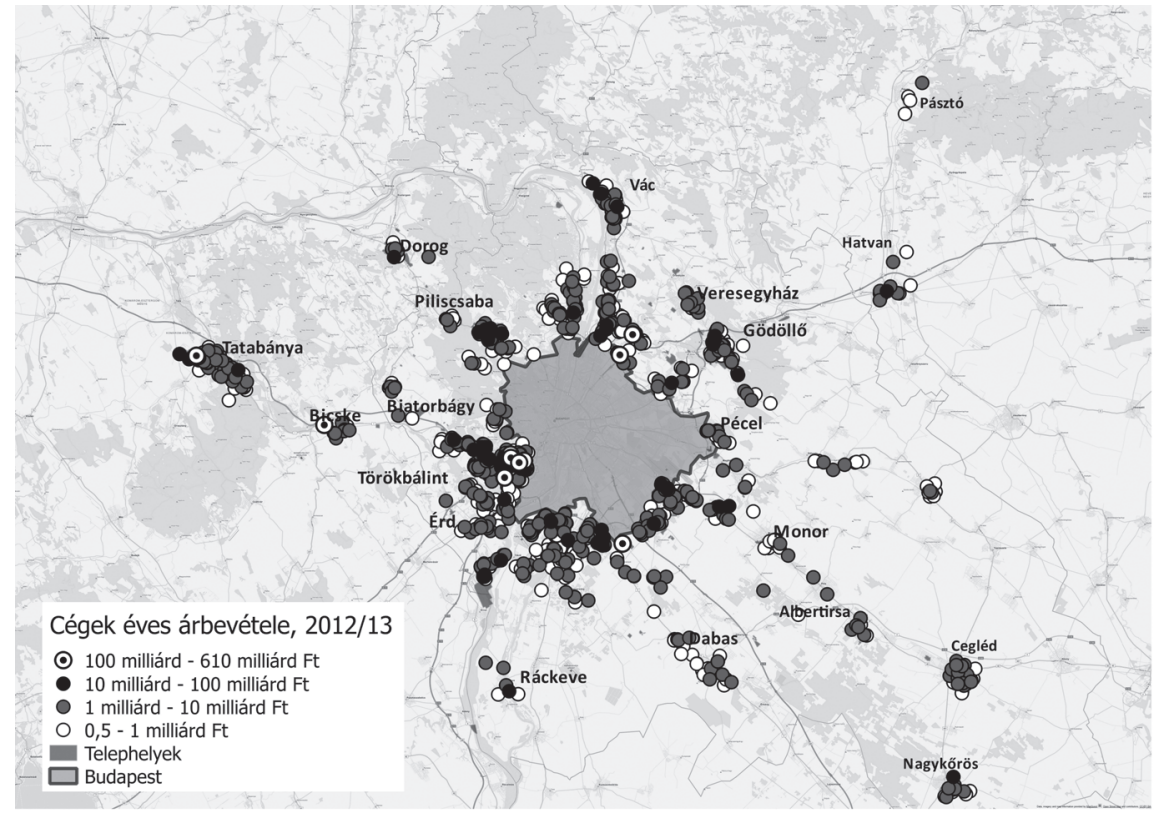

Forrás: saját szerkesztés. 


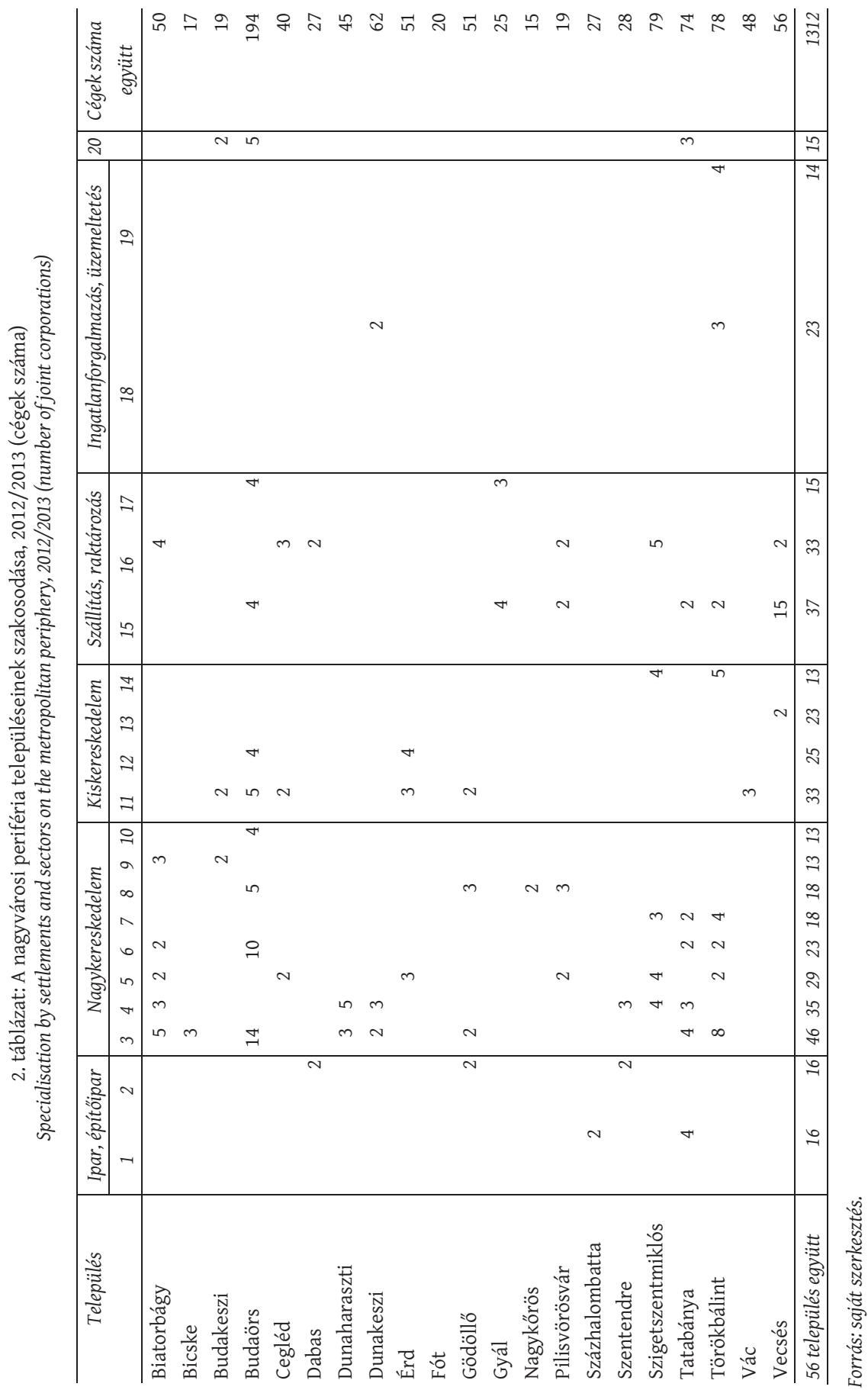


Jelmagyarázat a 2. táblázathoz: 1: Fémszerkezet gyártása; 2: Lakó- és nem lakóépület épitése; 3: Vegyes termékkörü nagykereskedelem; 4: Fa, épitöanyag szaniteráru nagykereskedelme; 5: Fémáru, szerelvény, fütési berendezés nagykereskedelme; 6: Egyéb, máshová nem sorolt gép, berendezés nagykereskedelme; 7: Élelmiszer, ital, dohányáru vegyes nagykereskedelme; 8: Gabona, dohány, vetömag, takarmány nagykereskedelme; 9: Vegyi áru nagykereskedelme; 10: Elektronikus háztartási cikk nagykereskedelme; 11: Személygépjármü-, könnyügépjármü-kereskedelem; 12: Gépjámü-üzemanyag kiskereskedelme; 13: Élelmiszer jellegü bolti vegyes kiskereskedelem; 14: Egyéb gépjármü kereskedelem; 15: Egyéb szállitást kiegészito" szolgáltatás; 16: Közúti áruszállitás; 17: Raktározás, tárolás; 18: Saját tulajdonú ingatlan adásvétele; 19: Saját tulajdonú, bérelt ingatlan bérbeadása, üzemeltetése; 20: Mérnöki tevékenység, müszaki tanácsadás.

A táblázatban a legalább 15 cégnek helyt adó települések szerepelnek.

a térképek QGIS programmal készültek. Az adatok interpretálhatósága érdekében a vállalkozáskoncentrációk helyszíni felmérése is megtörtént.

A települési bontású cégadatbázis lehetőséget ad az ágazati specializáció, azaz a gazdaság (jelen esetben a periféria nagy árbevételü cégei) települési szintű szakosodásának vizsgálatára (2. táblázat). Az adatok alapján csak néhány ágazatban koncentrálódnak a cégek egy-egy központban. Így az elektronikai ipar és gépgyártás Tatabányán és Cegléden, a gyógyszeripar Gödöllőn összpontosul. Az összetettebb tartalmú szolgáltatások viszont alig néhány települést érintenek. A mérnöki tevékenység és tanácsadás a legnagyobb cégközpontokban koncentrálódik (Tatabánya, Budaörs), az ingatlanforgalmazás, -bérbeadás és -üzemeltetés egyértelmű központja Törökbálint. Kiemelendö, hogy azok a cégek, amelyek a cégvezetést és az értékeloaállítást is azonos telephelyen kívánják megoldani, nagy számban vannak jelen a periférián. A legnagyobb árbevételű cégek, mint a kiskereskedelmi láncok (Tesco, Spar, Penny Market), a gépipari (Carterpillar, Zollner, Ibiden) vagy akár az ingatlanbérléssel foglalkozó (Immochan) cégek irányító és termelő tevékenységeiket integráltan végzik egyegy periferikus telephelyen. Úgy tűnik tehát, hogy a fokozott elosztásigényü cégek megfelelő környezetet találnak a központi városon kívül is ahhoz, hogy irányítási, termelési és termeléstámogató funkcióikat ne telepítsék térben széttagolva; azaz sem az ágazati, sem a funkcionális specializáció jeleit nem figyelhetjük meg a periférián. Szintén nem mutathatók ki a globális értéktermelés egy-egy ágazatára, munkafolyamatára specializálódó céghálózatok, együttmüködések. A szakirodalomban előre jelzett gazdasági térstruktúrát tehát nem találhatjuk meg a budapesti nagyvárosi tér perifériáján. Ezek alapján a metropolisztér a globális értéktermelés és -elosztás köreibe kevéssé integrált városi gazdaságnak tűnik, amely kevés speciális szolgáltatást és terméket képes nyújtani a külpiacok számára. A globális gazdaságba való betagozódásnak egy másik olvasata azonban éppen a globalizációnak „kitett” és számára „érdektelen” helyek megkülönböztetése. A neoliberális átalakulás folyamata differenciálja a nagyvárosi tér egyes településeit aszerint, hogy az milyen mértékben képes részt venni a globális érték-előallítás folyamatában. A cégek koncentráltsága egy-egy településen közvetetten utal ennek a szelekciós folyamatnak a korlátok közé szorított vagy éppen spontán jellegére. 


\section{Neoliberalizáció a gazdasági tér morfológiájában}

A cégadatbázis lehetővé tette a cégek térbeli eloszlásának települési szintű vizsgálatát. A gazdaság morfológiája a periféria egyes helyein koncentráltabb, máshol jóval szétszórtabb eloszlását mutatja a cégeknek. A gazdasági társaságok szétszóródása a periférián a város szabályozatlan szétterülésének vizuálisan egyik legmeghatározóbb jelensége, hiszen elsősorban az autópályák környéki föutakat és alsóbb rendủ utakat érinti. Kiemelkedően sok cég található szórt elrendeződésben, vállalkozói területeken kívül a 2-es főút Dunakeszi és Göd közötti szakasza mentén, a 11-es fóút Budapest és Szentendre közötti szakaszán, valamint a Csepelt Halásztelekkel összekötő út mentén. Annak okait kerestem, hogy milyen hatások következtében szóródnak szét a periféria egyes településein a cégek és miért tömörülnek máshol vállalkozói zónákba. Az eltérés az egyes települések között ugyanis számottevő.

A térképi adatbázis szerint a cégek koncentráltságát nem kizárólag a telephelyek megközelíthetősége határozza meg (2. és 3. ábra). Ennek egyik oka lehet, hogy a periféria adottságaiban nincsenek jelentős különbségek: a funkcionális várostérség és a metropoliszrégió ellátottsága közel hasonló. A nagy árbevételű cégek leginkább a periféria legdinamikusabb gazdasági központjaiban tömörülnek vállalkozói zónákba. Figyelemre méltó, hogy ezek a központok a rendszerváltozást megelőzően megvalósult vagy elkezdett autópályák menti

2. ábra: Cégek éves árbevétele és telephelyeik az északi várostérségben, 2012/2013

Annual income of companies and their location in the Northern metropolitan area, 2012/2013

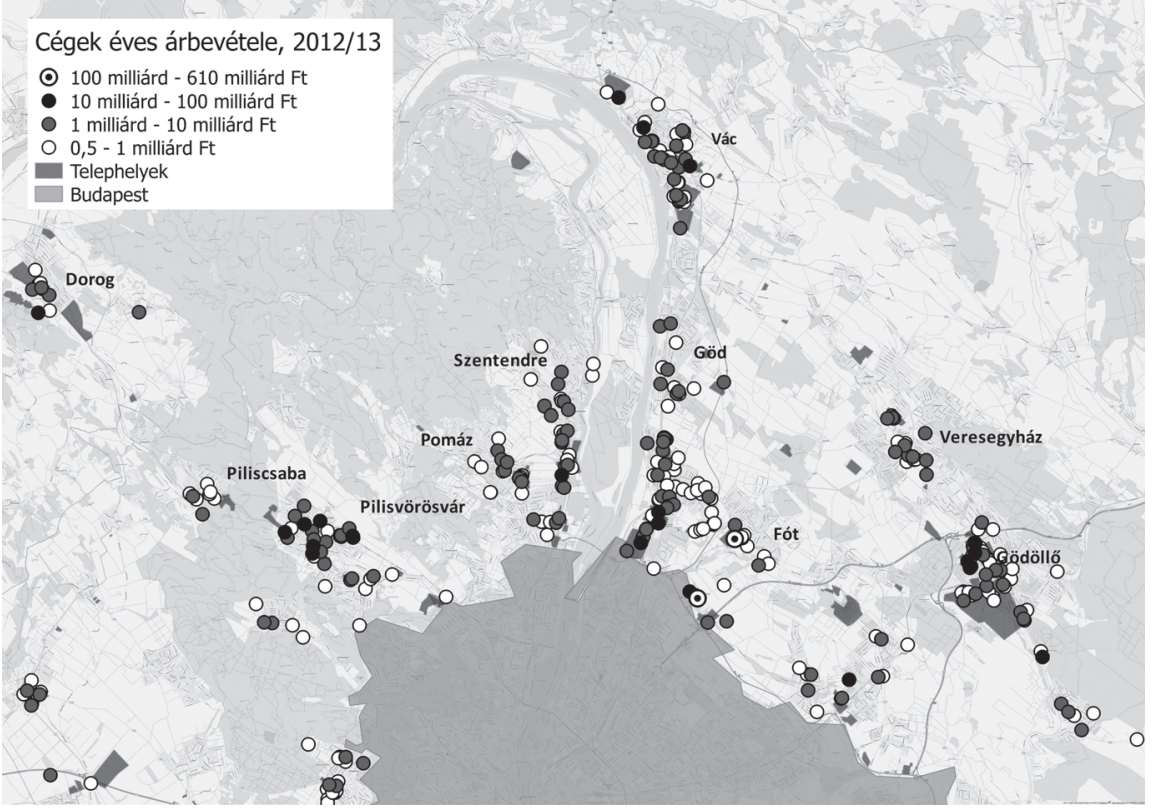

Forrás: saját szerkesztés. 
3. ábra: Cégek éves árbevétele és telephelyeik a déli várostérségben, 2012/2013

Annual income of companies and their location in the Northern metropolitan area, 2012/2013

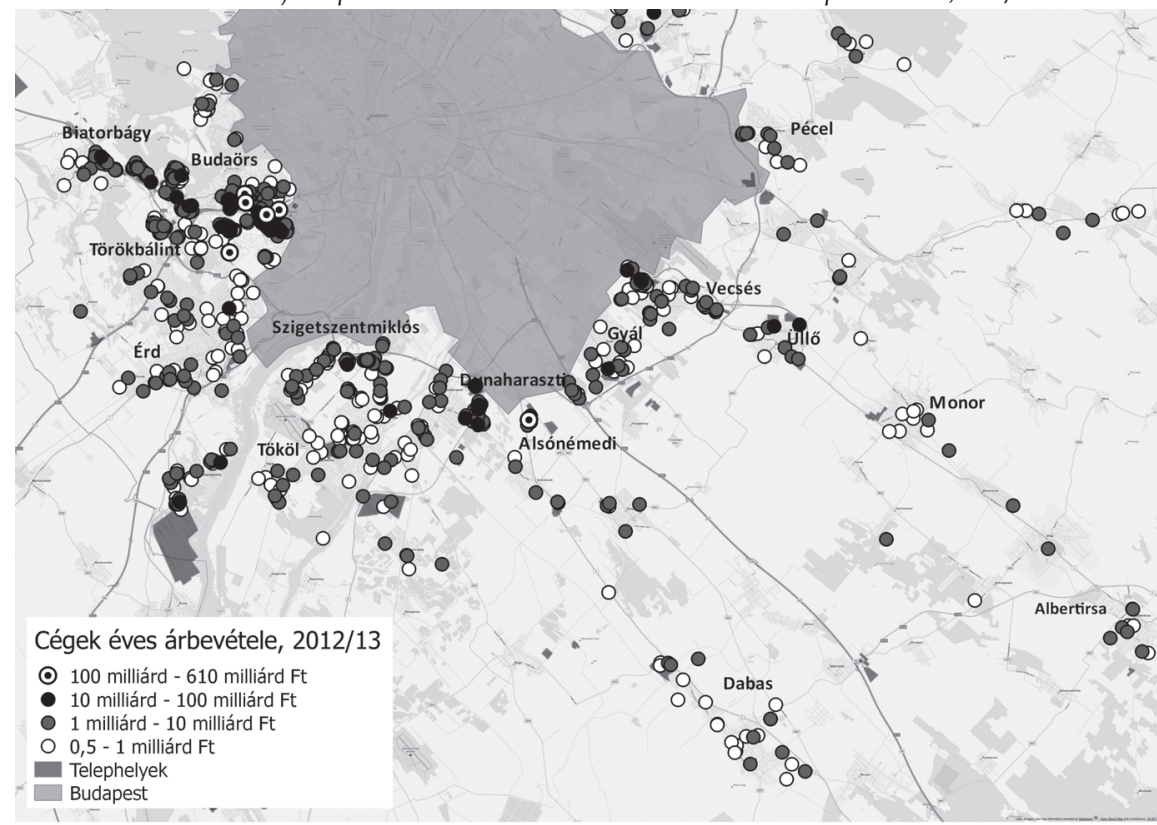

Forrás: saját szerkesztés.

településeken találhatók nagy számban. Egyes szocialista ipari múlttal rendelkező központokban - Vác, Szigetszentmiklós, Tatabánya, Solymár - a nagy árbevételü cégek nem újították meg a korábbi telephelyeket, jóval gyakrabban választották az újonnan kialakított ipari parkokat. Előfordult ugyan, hogy az egykori telephelyen szakmai befektető vette át a termelés egy részét, de gyakrabban megesett, hogy az egykori ipari telephelyeken kívül extenzív ipariparkfejlesztésbe fogtak az önkormányzatok és a piaci szereplők. Vác az előbbi példákkal szemben szakítani kívánt ipari múltjával. Itt a termelés politikai alulértékelése a vállalkozások koordinálatlan telephelyszervezését vonta maga után, azaz a vállalkozások szétszóródtak a város területén. Gödöllő vagy Százhalombatta az előzőektől eltérő pályát járt be, itt az ipari területek reorganizációja volt a jellemző. Mindkét városban továbbra is prosperál a hagyományos ipari terület, de mindkét helyszínen épült ipari park, amelyet szintén nagyszámú cég választott telephelyéül. Ebből következően a vállalkozások koncentrált megjelenése és a rendszerváltozást megelőző ipari profil között sejthetünk összefüggést. A vegyipar Gödöllőn és Százhalombattán vélhetően megalapozta a tőkés átalakulás sikerét, míg a nehézipari profil hagyományos telephelyeinek elégtelensége jobbára új ipari parkok felé irányította a cégeket, illetve szétszórta őket a városok területén.

Feltételezhetően az önkormányzati koordináció sem játszott és játszik jelentéktelen szerepet a települések másik csoportjában. Ezek az agglomerációs 
externáliák következtében „felnőtt” gazdasági koncentrációk, amelyeknek túlnyomó többségében a vállalkozások térben koncentráltan jelennek meg. Budaörs, Törökbálint, Vecsés, Biatorbágy, Dunaharaszti, Alsónémedi esetében szükségszerüen fel kellett lépni valamilyen helyi érdekérvényesítésnek ahhoz, hogy nagyszámú cég koncentráltan letelepüljön. Ellenpéldaként Érd, Dabas, Gyál, Halásztelek említhető, ahol bár számos cég van jelen, de szétszórtan települve. Ezek a települések általában gyorsan és spontán növekedtek, nagy részüket hatósági akarat hozta létre a 20. század folyamán (Berkovits 1976). Úgy tűnik tehát, hogy a tervezetlen módon nőtt települések közül azok, amelyek a rendszerváltozást megelőzően robbanásszerű társadalmi átalakulást éltek át, netán közigazgatási jogállásuk is rendezetlen volt, nagyobb arányban maradtak passzívak a tőkés átalakulás okozta gazdasági átalakulással szemben. Ugyanakkor számos példát láthatunk arra nézve, hogy olyan települések voltak képesek kiemelkedni a környezetükből átgondolt vállalkozáspolitikával, településrendezési eszközeik célszerű alkalmazásával, amelyek helyi kapacitásaik és tőkéjük híján csakis saját reflexivitásukban, átgondolt gazdaságpolitikai gyakorlat kialakításában bízhattak (Alsónémedi, Vecsés). Tapasztalataim alapján a nagyvárosi periférián még egymáshoz rendkívül hasonló közlekedési kapcsolatok mellett is léteznek települések, amelyek előszeretettel válnak a tőkebefektetések helyszínévé, és vannak, amelyek csak korlátozottan képesek a helyi vállalkozások számát gyarapítani. Hasonlóképpen léteznek önkormányzatok és helyi vezetők, akik a helyi közösség vélt igényeiből építenek politikai stratégiát, ezzel vállaltan távolságot tartva a külső befektetői nyomástól.

\section{A periféria politikai gazdaságtanának néhány jellemzője}

A helyek szemmel láthatóan eltérő módon kezelik a neoliberalizációs folyamat rájuk nehezedő nyomását; Golubchikov és Phelps (2011) szóhasználatában más és más módon sajátítják el a neoliberális átalakulást. Ebből arra következtethetünk, hogy - a társadalom helyi viszonyain túl - az állam és a tőke viszonyában helyi eltérések is lehetnek.

Milyen viszonyt ápol a helyi állam a tőkével, hogyan és milyen célok mentén használja az állami kontrollt a piaci folyamatok felett (vagy éppen fordítva, a tőke az állam felett), és milyen mechanizmusokon keresztül termeli magát újra a periféria? A települések kiválasztott csoportjában az állam különböző szintjeinek és intézményeinek, önkormányzati cégeknek, nagybefektetőknek a bevonásával készítettem félig strukturált interjúkat. A vizsgálati terület Tökölt, Szigetszentmiklóst és Dunaharasztit foglalta magában. ${ }^{3}$ Négy fó téma köré összpontosultak a beszélgetések.

A gazdasági átalakulás dinamikája. A vizsgált települések közül Szigetszentmiklós és Dunaharaszti kifejezetten keresett telephellyé vált a kétezres évek közepére, míg Tököl visszafogottabb érdeklődésre tarthatott számot. A főként 
logisztikára, termelésre és kereskedelemre épülő felfutás (2005-2008/9) idején számos befektető jelent meg. A konjunktúrát főként Szigetszentmiklóson követte stagnálás, enyhe visszaesés, amelyet a piaci igényekkel nem találkozó spekulatív logisztikai kapacitásoknak tulajdonítottak. Dunaharaszti a hitelpiaci válságot követően sem veszített lendületéből, a városban mindvégig zajlottak beruházások. Ennek okát az ipari beruházások nagyobb arányában, a tőkeerős vállalatok jelenlétében látták, amelyek dekonjunktúra idején is húzták magukkal a helyi beszállítókat.

A hely mint tóke. A megközelíthetőség, az elhelyezkedés az interjúalanyaim mindegyike szerint sikertényezőt jelent az üzleti vállalkozások számára. Az állam éppen ezért igyekszik a hely feletti rendelkezés jogait - legyen az tulajdon, bérleti jog vagy éppen a földhasználat közjogi feltételeinek alakítása - minél erősebben szabályozni. Ennek egyik fontos lépése volt a 2013-ban elfogadott földforgalmi törvény, amely az állam tulajdonosi szerkezetet befolyásoló szerepének egyik állomása. A földtulajdonszerzés korlátozása a periférián a gazdasági hasznosítást is ellehetetleníti, de legalább az óriási alapterületű beruházások - ebben az esetben leginkább a logisztikai projektek - elé jelentős akadályokat gördít. A törvény egyik interjúalanyom megfogalmazásában kedvezőtlen hatással bír, mivel nem kezeli kellően differenciáltan a nagyváros hatókörzetében található területeket, amelyek a termelésből származó értéknél jóval magasabb hozamokra képesek.

Az állam hatalomgyakorlása és szerepe a gazdasági fejlódésben. Az állam és a tőke neoliberális viszonyai sajátos hatalomgyakorlási mechanizmusokat eredményeznek. Az állam olyan helyeken is megjelenik, ahol korábban kevésbé explicit módon volt jelen. Így a központi állam és az üzleti szereplők kapcsolata közvetlenebbé válik: az állam aktív fellépésével koordinálja a vállalkozásokat saját érdekei mentén. A piaci szereplőként viselkedő állam áthatja a közigazgatási intézményrendszer egészét, így a helyi állam szintjét is. Az önkormányzat (jelenleg a járási szint) kezében az építéshatósági eljárás a legütőképesebb eszköz, hiszen így közvetlen ráhatásuk van arra, hogy illetékességi területükön mi épülhet. Ebben az eljárásban nyomozható leginkább a helyi állam és a befektetők közötti kapcsolat. A kormányzati centralizáció a korábbi jogok visszavételével csorbát ejt az önkormányzatok korábbi viszonylagos autonómiáján, ezért sérelmes az önkormányzat számára. Egymással konkuráló félként jelenik meg a helyi önkormányzat és a járási hivatal. A harc tárgya pedig a fizikai környezet alakítása feletti kontroll.

Az önkormányzat mint hatalmi tényező. Egyetlen interjúalany sem támasztotta alá a fóáramú szakirodalom azon vélekedését, hogy a neoliberális piaci viszonyok között az önkormányzatok passzív vagy kiszolgáltatott helyzetben lennének. A válaszok spektruma az üzleti vállalkozásokat segítö önkormányzat képétől a helyi közösségi érdekeket minden ellenérdeken keresztül győzelemre vivő helyi államon át egészen a gazdaságot meghatározó, felettes hatalmi pozícióban lévő önkormányzat képéig terjedt. A helyi állam magáról tehát a semlegestől 
(de nem kiszolgáltatottól) az elnyomóig sok mindent gondol, és ez a változékonyság akkor is figyelemre méltó, ha tudatában vagyunk: az egyes szereplők véleménye az eleve politikai nyomás alatt álló intézmények által meghatározott.

\section{Összegzés}

Tanulmányomban a budapesti nagyvárosi periféria tértermelési folyamatait kutattam. A vállalkozások elhelyezkedésének vizsgálatával érveltem amellett, hogy a budapesti nagyvárosi tér gazdasága inkább a méretgazdaságos városi piacra épül, mintsem a globális termelési hálózatokba való betagozódásra. A nyugat-európai várostérségek trendjeinek megfelelően a városi periféria gazdaságszerkezete a statisztikai adatok szerint változatosabbá válik és hasonul a központi városéhoz. Ugyanakkor a periferikus központok erősödése nem vezet az egyes települések specializációjához. Cégadatok elemzésével arra mutattam rá, hogy a budapesti várostérség gazdaságát saját létfeltételeinek megteremtése húzza, és az ágazati specializáció korlátos mértékéből adódóan kevés termékkel, szolgáltatással képes megjelenni a világpiacon. Hasonló módon megkérdőjelezhető a vállalkozások központi városból történő kitelepülésének térformáló hatása, mivel a statisztikai adatok új cégek megjelenésére utalnak, nem pedig azok áthalmozódására a városrégió egyes övezetei között.

A cégadatok térképi megjelenítése nyilvánvalóvá tette, hogy a periféria egymáshoz közel fekvő településein is eltérő módon koncentrálódnak a vállalkozások. A társadalmi kontextus és a termelési hagyományok következtében a piaci erők nyomása eltérő gazdasági morfológiát eredményez a településeken. Helyi eltéréseket a kontextus- és útfüggő gazdasági átalakuláson túl az állam és a tőke viszonyában jelentkező helyi sajátosságok is okozhatnak. Múlékony feltételezésnek bizonyult a gyenge állam toposza, amely szinte automatikusan került a neoklasszikus gazdaságtanból a társadalomföldrajz axiómái közé. Az interjúk tanúsága szerint az államnak különösen fontos szerepe van a helyi gazdaság átalakulásában. Nyomon követhető törekvés a központi állam hatalomkoncentrációja, amely a hatósági jogkörök magasabb területi szintekre történő összevonásában érhető tetten (az építéshatósági eljárás járási szintre helyezése, a földforgalmi törvény rendelkezései, a hatósági jogkörök központosítása). A tér termelése feletti ellenőrzés centralizációja a neoliberalizációs folyamatba illeszkedik, de annak konkrét mechanizmusai helyi sajátosságokat mutatnak.

\section{Köszönetnyilvánítás}

Az adatbázis térképezésének technikai megoldásáért köszönet illeti Orosz Balázst (Aquaprofit Zrt.). 


\section{Jegyzetek}

1 A településkör lehatárolása követi a 2010-2012 között a Szegedi Tudományegyetem Gazdaságés Társadalomföldrajz Tanszékének közreműködésével készült ESPON POLYCE projekt módszertanát. Az 56 település azokat a foglalkoztatási központokat takarja, amelyekben legalább 1000 munkahely volt elérhető a közvetlen (funkcionális várostérség), illetve legalább 3000 munkahely a tágabb (metropoliszrégió) várostérségben. A szűkebb és tágabb várostérség lehatárolásának alapja a Budapestre ingázó foglalkoztatottak aránya (funkcionális várostérség: minimum $25 \%$ beingázó; metropoliszrégió: minimum $15 \%$ beingázó). A lehatárolás pontos módszertanáról lásd Kovács, Szabó 2013; Szabó, Szabó, Kovács 2014.

2 A TEÁOR '03 és TEÁOR '08 statisztikai osztályozás közvetlenül nem megfeleltethető egymásnak az ágazatok szintjén. A hosszabb távú folyamatok nyomon követése érdekében ezért ágazatcsoportokban összegeztem az egyes ágazatokban müködő cégeket. Mivel azonban az így képzett ágazatcsoportokban sem fedik tökéletesen egymást a kétféle osztályozás szerinti tevékenységek, az utolsó vizsgált évnél csak a növekedés vagy a csökkenés trendje mérvadó.

3 A településeket a cégadatbázis térképi megjelenítésekor kirajzolódó egyedi gazdasági morfológia (a koncentráltan és szétszórtan települt cégek váltakozása településről településre) alapján választottam ki. 2015 júniusa és augusztusa között hét interjú készült: négy önkormányzati tisztviselővel vagy politikussal, egy önkormányzati cég vezetőjével, egy nagybefektetővel és egy országos szintü politikussal. Az interjúalanyokat kérésüknek megfelelően úgy anonimizáltam, hogy települési kötődéseik is rejtve maradjanak.

\section{Irodalom}

Axenov, K., Brade, I., Bondarchuk, E. (2006): The transformation of urban space in post-soviet Russia. Routledge, Oxford

Berki, M. (2014): Return to the road of capitalism: Recapitulating the post-socialist urban transition. Hungarian Geographical Bulletin, 3., 319-334. http://doi.org/9bc

Berkovits Gy. (1976): Világváros határában. Szépirodalmi Könyvkiadó, Budapest

Bodnár, J. (2000): Fin de millénaire Budapest: Metamorphoses of urban life. University of Minnesota Press, Minneapolis

Bontje, M., Burdack, J. (2011): Post-suburbia in continental Europe. In: Phelps, N., Wu, F. (eds.): International perspectives on suburbanization. A post-suburban world. Palgrave Macmillan, Houndmills, Basingstoke, Hampshire, 143-162. http://doi.org/9bd

Borén, T., Gentile, M . (2007): Metropolitan processes in post-communist states: an introduction. Geografiska Annaler B, 2., 95-110. http://doi.org/d62dt9

Boros L. (2010): Az új városszociológia születése. In: Jancsák Cs., Pászka I., Nagy G. (szerk.): Állandó párbeszédben. Belvedere Meridionale, Szeged, 64-76.

Bose, M. (2001): Raumstrukturelle Konzepte für Stadtregionen. In: Brake, K., Dangschat, J. S., Herfert, G. (Hrsg.): Suburbanisierung in Deutschland. Aktuelle Tendenzen. Leske-Budrich, Opladen, 247-260. http://doi.org/9bf

Brake, K. (2001): Neue Akzente der Suburbanisierung - Suburbaner Raum und Kernsatdt: eigene Profile und neuer Verbund. In: Brake, K., Dangschat, J. S., Herfert, G. (Hrsg.): Suburbanisierung in Deutschland. Aktuelle Tendenzen. Leske-Budrich, Opladen, 15-26. http://doi.org/9bg

Brake, K., Einacker, I., Mäding, H. (2005): Kräfte, Prozesse, Akteure - zur Empirie der Zwieschenstadt. Verlag Müller-Busmann, Wuppertal

Brenner, N., Theodore, N. (2002): Cities and the geographies of actually-existing neoliberalism. Antipode, 3., 349-379. http://doi.org/b95ppg 
Burdack, J., Herfert, G., Rudolph, R. (2005): Europäische metropolitane Peripherien. Leibniz-Institut für Länderkunde, Leipzig

Burger, M, Meijers, E. (2012): Form follows function? Linking morphological and functional polycentricity. Urban Studies, 5., 1127-1149. http://doi.org/bnzvv7

Champion, T. (2001): Urbanization, suburbanization, counterurbanization and reurbanization. In: Paddison, R. (ed.): Handbook of urban studies. Sage, London, 143-161. http://doi.org/9bh

Csanádi G., Csizmady A. (2002): Szuburbanizáció és társadalom Tér és Társadalom, 3., 27-55.

Danielzyk, R. (2012): Discourse on spatial planning policy in metropolitan regions - the construction of (new) peripheries? disP - The Planning Review, 2., 27-33.

Davoudi, S. (2003): Polycentricity in European spatial planning: from an analytical tool to a normative agenda. European Planning Studies, 8., 979-999. http://doi.org/cm4wjd

De Goei, B., Burger, M., van Oort, F., Kitson, M. (2010): Functional polycentrism and urban network development in the Greater South East, United Kingdom: evidence from commuting patterns, 1981-2001. Regional Studies, 9., 1149-1170. http://doi.org/dvtsh5

Enyedi Gy. (2011): A város növekedés szakaszai - újragondolva. Tér és Társadalom, 1., 5-19.

Fujita, M. (2002): Economies of agglomeration: cities, industrial location and regional growth. Cambridge University Press, Cambridge http://doi.org/9bj

Gentile, M., Tammaru, T., van Kempen, R. (2012): Heteropolitanization: social and spatial change inCentral and East European cities. Cities, 5., 291-299. http://doi.org/f22m2t

Golubchikov, O., Phelps, N. (2011): The political economy of place at the post-socialist urban periphery: governing growth on the edge of Moscow. Transactions of the Institute of British Geographers, 3., 425-440. http://doi.org/fw5jbs

Hall, P. (2009): Polycentricity. In: Kitchin, R., Thrift, N. (eds.): International encyclopedia of human geography. Vol. 8. Elsevier, Amsterdam, London, Oxford, 260-264. http://doi.org/bfm346

Hall, P., Pain, K. (2006): From metropolis to polyopolis. In: Hall, P., Pain, K. (eds.): The polycentric metropolis. Learning from mega-city regions in Europe. Earthscan, London, 3-16.

Harvey, D. (1978): The urban process under capitalism: A framework for analysis. International Journal of Urban and Regional Research, 1-4., 101-131. http://doi.org/fqgkq7

Harvey, D. (1990): Accumulation through urbanization. Reflections on "post-modernism" in the American city. Perspecta, 26., 251-272. http://doi.org/b2j4gj

Hirt, S. (2013): Whatever happened to the (post)socialist city? Cities, Supplement 1., S29-S38. http://doi.org/9bk

Kaminer, T., Robles-Durán,M., Sohn, H. (2011): Urban asymmetries. Studies and projects of neoliberal urbanization. 010 Publishers, Rotterdam

Keserü, I. (2013): Post-suburban transformation in the functional urban region of Budapest in the context of changing commuting patterns. Doktori értekezés, Szegedi Tudományegyetem Földtudományi Doktori Iskola

Kiss V. (2014): „Tudják, de mégis teszik”. Slavoj Žižek és a kapitalizmus mint ideológia. Replika, 5., $129-150$.

Kitchin, R. (2009): Space II. In: Kitchin, R., Thrift, N. (eds.): International encyclopedia of human geography. Vol. 10. Elsevier, Amsterdam, New York, Oxford, 268-275. http://doi.org/fpwhds

Kovács Z. (2005a): Budapest funkcionális átalakulásának főbb vonásai a rendszerváltozás után. Földrajzi Közlemények, 1-2., 83-102.

Kovács Z. (2005b): A társadalmi-gazdasági átalakulás területi jellemzői Budapest városrégiójában. In: Dövényi Z., Schweitzer F. (szerk): A földrajz dimenziói: Tiszteletkötet a 65 éves Tóth Józsefnek. MTA Földrajztudományi Kutatóintézet, Budapest, 59-82.

Kovács Z. (2010): A szocialista és posztszocialista urbanizáció értelmezése. In: Barta Gy., Beluszky P., Földi Zs., Kovács K. (szerk): A területi kutatások csomópontjai. MTA Regionális Kutatások Központja, Pécs, 141-157.

Kovács Z., Szabó T. (2013): A policentrikus városfejlődés térfolyamatai Közép-Európában. Településföldrajzi Tanulmányok, 1., 6-19.

Krugman, P. (2000): Where in the world is the new economic geography. In: Clark, G. L., Fedman, M. P., Gertler, M. S. (eds.): The Oxford handbook of economic geography. Oxford University Press, Oxford, 49-60. 
Kukely Gy. (2006): A nagyvárosok felértékelődése a külföldi működőtőke-beruházások telephelyválasztásában. Tér és Társadalom, 4., 111-125.

Kulcsar, L. J., Domokos, T. (2005): The post-socialist growth machine: the case of Hungary. International Journal of Urban and Regional Research, 3., 550-563. http://doi.org/b83xzk

Lefebvre, H. (1991): The production of space. Blackwell, Oxford

Maier, G., Tödtling, F. (2001): Regional- und Stadtökonomik 1. Standorttheorie und Raumstruktur. Springer, Wien, New York

Mainz, M. (2005): Ökonomische Bewertung der Siedlungsentwicklung. Ansätze einer effizienten Siedlungspolitik. V\&R Unipress, Göttingen

Malmberg, A. (2009): Agglomeration. In: Kitchin, R., Thrift, N. (eds.): International Encyclopedia of Human Geography. Volume 1. Elsevier, Amsterdam, New York, Oxford, 48-53. http://doi.org/csb8p4

Meijers, E. (2005): Polycentric urban regions and the quest for synergy: is a network of cities more than the sum of the parts? Urban Studies, 4., 765-781. http://doi.org/bh39hc

Pálné Kovács I. (2009): Régiók és fejlesztési koalíciók. Politikatudományi Szemle, 4., 37-60.

Pálné Kovács I. (2010): Városi terek kormányzása és a városi rezsimek. Egy induló kutatás margójára. Tér és Társadalom, 4., 3-27.

Peet, R., Hartwick, E. (2009): Theories of development. Contentions, arguments, alternatives. Guilford Press, New York

Phelps, N., Wu, F. (2011): Introduction. In: Phelps, N. A., Wu, F. (eds.): International perspectives of suburbanization. A post-suburban world? Palgrave Macmillan, Houndmills, Basingstoke, Hampshire, 1-12. http://doi.org/9bm

Sági Zs. (2000): A budapesti agglomerációs övezet gazdasági térszerkezete és kapcsolatrendszere. Ph.D. értekezés, Pécsi Tudományegyetem, Természettudományi Kar

Sassen, S. (2001): Cities in the global economy. In: Paddison, R. (ed.): Handbook of urban studies. Sage, London, 256-272. http://doi.org/9bn

Scott, A. J., Agnew, J., Soja, E., Storper, M. (2001): Global city-regions. In: Scott, A. J. (ed.): Global city-regions. Oxford University Press, New York, 11-30.

Sieverts, T. (1999): Zwischenstadt - zwischen Ort und Welt, Raum und Zeit, Stadt und Land. Vieweg, Basel, Berlin http://doi.org/9bp

Smith, N. (1982): Gentrification and uneven development. Economic Geography, 2., 139-155. http://doi.org/dn56mh

Stanilov, K. (2007): Taking stock of post-socialist urban development. In: Stanilov, K. (ed.): The postsocialist city. Urban form and space transformations in Central and Eastern Europe after socialism. Springer, Dordrecht, 3-17. http://doi.org/cm2387

Sýkora, L., Bouzarovski, S. (2012): Multiple transformations: Conceptualising the post-communist urban transition. Urban Studies, 1., 43-60. http://doi.org/bzb43z

Szabó, T., Szabó, B., Kovács, Z. (2014): Polycentric urban development in post-socialist context: the case of the Budapest Metropolitan Region. Hungarian Geographical Bulletin, 3., 287-301. http://doi.org/9bq

Szirmai V. (2011): A nagyváros szélén: a városi terjeszkedés térbeli társadalmi problémái. Tér és Társadalom, 1., 20-41.

Szirmai, V., Váradi, Zs., Kovács, Sz., Baranyai, N., Schuchmann, J. (2011): Urban sprawl and its spatial, social consequences in the Budapest Metropolitan Region. In: Szirmai V. (ed.): Urban sprawl in Europe. Similarities or differences? Aula Kiadó, Budapest, 141-186.

Timár J. (1999): Elméleti kérdések a szuburbanizációról. Földrajzi Értesító, 1-2., 7-31.

Timár J. (2010): Van-e posztszocialista urbanizáció? In: Barta Gy., Beluszky P., Földi Zs., Kovács K. (szerk): A területi kutatások csomópontjai. MTA RKK, Pécs, 121-140.

Timár, J., Váradi, M. M. (2001): The uneven development of suburbanization during transition in Hungary. European Urban and Regional Studies, 4., 349-360. http://doi.org/cv47vf

van den Berg, L. (1982): Urban systems in a dynamic society. Gower, Aldershot

Venables, A. J. (2008) New economic geography. In: The new Palgrave dictionary of economics. http://www.dictionaryofeconomics.com/article?id=pde2008_E000247 (Letöltés: 2012. május 20.) 